8. Pometun, O. I. (2018). Krytychne myslennia yak pedahohichnyi fenomen. [Critical thinking as pedagogical phenomenon]. Kiev.

9. Savchenko, S. V. (2019). Formuvannia krytychnoho myslennia yak odna z umov uspishnoi sotsializatsii suchasnoi osobystosti. [Critical thinking formation as one of the conditions of successful socialization of a modern personality]. Luhansk.

10. Surmin, Yu. P. (2012). Keis-stadi: arkhitektura i mozhlyvosti. [Case-study: architecture and possibilities]. Kiev.

11. Tkachenko, L. I. (2012). Teoretychni zasady tekhnolohii formuvannia krytychnoho myslennia maibutnikh uchyteliv pochatkovoi shkoly. [Theoretical grounds of future primary teachers' critical thinking formation technology] [Elektronnyi resurs].

http://nbuv.gov.ua/UJRN/Nzspp_2012_7_45

URL:

12. Tyaglo, A. V., Voropaj, T. S. (1999). Kriticheskoe myshlenie: Problema mirovogo obrazovaniya XXI veka. [Critical thinking: The problem of world education of the $21^{\text {st }}$ century]. Har'kov.

13. Shakhov, V. I., Kylivnyk, A. M., Melnyk, I. M. (2018). Rozvytok krytychnoho myslennia yak umova formuvannia profesiinoi identychnosti maibutnikh uchyteliv. [Critical thinking development as a condition of future teachers' professional identity formation].

14. Yahodnikova, V. V. (2009). Zastosuvannia tekhnolohii rozvytku krytychnoho myslennia $u$ protsesi pidhotovky maibutnikh fakhivtsiv. [The use of critical thinking development technology in the future specialists' training]. Kiev.

\section{ВІДОМОСТІ ПРО АВТОРІВ}

ОМЕЛЬЯНЕНКО Наталія Віталіївна кандидат психологічних наук, доцент, доцент кафедри іноземних мов Льотної академії Національного авіаційного університету.

Наукові інтереси: інноваційні технології навчання майбутніх фахівців.

ОМЕЛЬЯНЕНКО Світлана Віталіївна кандидат педагогічних наук, професор, професор кафедри соціальної роботи, соціальної педагогіки та психології Центральноукраїнського державного педагогічного університету імені Володимира Винниченка.

Наукові інтереси: вдосконалення професійної підготовки майбутніх соціальних педагогів.

\section{INFORMATION ABOUT THE AUTHORS}

\section{OMELIANENKO Nataliia Vitaliivna}

Candidate of Psychological Sciences, Associate Professor, Associate Professor of Foreign Languages Department of Flight Academy of National Aviation University.

Circle of research interest: innovation technologies of future specialists' education.

OMELIANENKO Svitlana Vitaliivna Candidate of Pedagogical Sciences, Professor, Professor of Social Work, Social Pedagogics and Psychology Department, Volodymyr Vynnychenko Central Ukrainian State Pedagogical University.

Circle of research interest: improvement of future social teachers' professional training.

Стаття надійшла до редакиії 01.11.2020 p.
POLISHCHUK GannaVitalievna Ph.D in Philology, Assistant Professor, Assistant Professor of the Chair of the English Language and its Teaching Methods, Volodimir Vinnichenko Central Ukrainian State Pedagogical University ORCID:https://orcid.org/0000-0002-9547-4959 e-mail:lopotova@ukr.net

\title{
PRACTICAL RELEVANCE OF TRAINING TECHNOLOGIES FOR FUTURE FOREIGN LANGUAGE TEACHERS
}

Formulation and justification of the relevance of the problem. Though the notion «training/or coaching/or skills development workshop/ workshop» has a comparatively short history (it appeared in the XIXc. as psychotherapy method, and later - as effective technology of the development of personality in practical psychology), it is widely used nowadays in educational sphere as the fruitful environment for formation of communicative skills [9, c. 9].

Analysis of the recent researches and publications.Examination of the material provides evidence that the essence and conceptual vision of organization of training workshops were carefully investigated by $P$. Bavina [1], R. Buckley, D. Capel [2] and others. Theoretical and methodological base of group training was explored by I. Vachkov [4]; of professional training by A. Markova [6]; psychological - by K. Milyutina [8]. The peculiarities of training technologies in educational process of high school were examined by L. Bondareva [3], A. Grigoreva [12], O. Kerik [5], N. Fedorenko [10] and others. 
Education is now increasingly interested in training technologies with active usage of interactive and communicative studies as teachers have to find new ways of coming in terms with those they hope to teach and improve their skills of interpersonal communication, thus the study of interaction is one way of trying to enable sufficient conversation to take place to facilitate teaching and learning. In a study of training technologies there is a real hope for improving future teacher's effectiveness and develop their personal and professional skills because contemporary high education establishments prioritize not only traditional but also innovative educational technologies: coaching, mentoring, mediation, moderation and facilitation etc.

The purpose of the study is to highlight the practical value of training technologies as due to them students are provided with a high level of knowledge acquisition, qualitative skills and abilities having a perspective potential for the formation of their conflictological competence which is considered a fundamental competence of any future teacher.

The main material of the study. As it was experimentally proved by N. Fedorenko, the implementation of training technologies into educational process has been positively approved by the students due to several reasons: they are involved and interested in the subject; it is a link between theory and practice; it activates the learning and cognitive activity of the students; all students may be involved into the process; the possibility to learn new material in practice $[10$, c. 158]. Thus, the implementation and usage of training technologies stimulates self-realization and creative potential of the students and intensifies the process of education.

The overview of existing approaches to the study of training technology showed that training is a modern technology of education as it has clear algorithm of usage that guarantees the achievement of the goal due to interactive methods directed on productive cooperation of its participants. Thus, training technology is defined as specially organized procedure where not only the whole system of interconnections between aims, tasks, content, role playing and non role playing methods is realized but also the system of retrospectives and corrections $[1$, c. 15].

It is worth mentioning here that different authors singled out different types of training technologies such as trainings of personal growth, communication trainings, sociopsychological, socio-pedagogical etc. $[5, \mathrm{c}$. 138]; socio-psychological, training of personal growth, corporative and video training [3]; socio-psychological, training of personal growth, thematic, communicative, adopting decisions training, strategic and psychocorrectional. For the purposes of our study the following types are relevant for the formation of conflictological competence of future teachers: socio-pedagogical, decision-making training and communicative. Let us briefly consider the details of each type. Socio-pedagogical training is described as the form of active learning directed to acquire certain knowledge, skills, techniques and information aimed at forming the attitude of participants to certain ideas and problems and modeling the behavior in the group to change and improve the development of a personality [5, c. 139].

Decision-making training is aimed at solving concrete problems where the validity of decisions and individual overriding of obstacles is taken into consideration.

Communicative training is directed at the development of speaking skills and effective behavior in different communicative situations as language reflects the interconnection of the surrounding world with people cognizing it. New skills and knowledge gained due to this training presuppose certain change of stereotypes and behavior that can ruin communication and cause conflict interaction in pedagogical environment. The aim of this training is to acquire skills of effective pedagogical communication and constructive means of solving conflict situations, the development of empathy, tolerance and other professionally important qualities of a teacher, thus, communicative training should add much to the future teachers' communicative competence. It should be noted that communicative competence involves four areas of knowledge and skills: grammatical competence, which reflects knowledge of the linguistic code itself and includes knowledge of vocabulary and rules of word formation, pronunciation, spelling and sentence formation; sociolinguistic competence, which addresses the extent to which utterances are produced and understood appropriately and includes knowledge of speech acts; discourse competence, which involves of how to combine grammatical forms and meanings to achieve a unified or written text in different genres; and strategic competence which refers to the mastery of the communication strategies that enhance the effectiveness of communication.

It is widely accepted that for successful implementation of training technologies in the process of formation of professional competence of future foreign language teachers 
the following principles should be taken into consideration: the principle of active participation (involvement into group process of learning), the principle of voluntary participation (inner interest of a person in gaining knowledge), the principle of dialogic interaction (intrapersonal communication based on mutual respect of the participants), the principle of self-actualization (self-presentation, reflexion), principle of safety (confidentiality of personal information), the principle of openness (trust to other participants and self truth), the principle of partnership (interaction based on empathy, tolerance and mutual intelligibility). These principles create comfortable atmosphere in student's surrounding in the process of implementation of training technologies.

To achieve maximum results any training technology should correspond the following requirements to its organization: concrete aims, the usage of effective methods and exercises, supply with material recourses, necessary rules, time limit, correction and improvement of the procedures, qualified teacher-trainer able to motivate and involve students into active interest on the basis of sincerity, tolerance and cooperation. Also the following functions of the training should be highlighted: aiming function (to achieve the aim); motivational (motivation for effective cooperation); informational (revision of professional information); communicative (exchange of information); personal-cognitive (the enrichment of behavioral repertoire); relaxation (stress relieving actions); developmental (the qualitative change of a person while training) having constructive impact of the development of personality in different directions.

We fully agree with I.Shorobura and Ju.Tkachenko that training procedure is characterized by the following structure: introduction, body and conclusion, where the outline may consist of tables; schemes etc., and the correlation between the structural elements in every case may be different depending on the aims of the training, the duration, the level of preparedness of the group etc.

As for the practical implementation of training technologies it turned out that the following forms of organization of students' communication in the process of doing different interactive exercises have been widely used: individual-cooperative (all students take part, though they express themselves on the given topic in turn suggesting their ways of solving the problem); communication in pairs (dialogue); small groups communication (4-6 persons discussion of the task with further announcement of the common decision); role- play and business play (modeling of real situation in specially created problem situation). Taking into consideration the structure of the trainings certain exercises were selected for each structural component, for instance, the following exercises were chosen for introductory part of the training: training exercise "Clew»») in the form of a game (aim: the introduction of the participants and the creation of friendly atmosphere). The participants make a circle and each will have the opportunity to throw a clew to the other carefully taking his part of the thread telling about himself. The game stops only after all participants are involved in 'communicative web'. The questions for discussion are the following: What can you say about 'communicative web'? (it stretches from one to another, there is a danger of a mess as a result); What can happen if I pull my end of thread? (others will feel some tension); What will other people feel if one of the participants is angry or frustrated? After the discussion the game continues but the person who was the last, now begins it. When he gives the clew to the final participant, his name and hobby must be remembered. And the questions to be discussed are: What did you feel when you joined the circle and what do you feel now?

Training exercise is «Meeting» aimed at the development of imagination of the participants and their creative associations about themselves with the help of demonstrating the slide «Exotic garden» in the form of individualcooperative discussion. The participants are suggested to imagine themselves in the garden full of oranges, lemons, pomegranates, apples, plums, pears, avocado, kiwi and other exotic fruits and choose one of those. The following questions are discussed: What kind of fruit am I? (describing type, color, taste etc.); What fruit is this person associated with? Training exercise «The interview» is aimed at expressing one's point of view in pairs with the help of toy microphone. The participants interview each other asking the following questions: What are you future plans? What human qualities do you appreciate most of all? What is your favorite color? What are your favorite books? What movies do you enjoy?

Above mentioned training exercises give the possibility for the participants to know each other better, to demonstrate one's plus sides, to think over one's drawbacks and join the work actively.

Exercises of the main part of the training were directed on the formation of conflictological competence of future teachers, broadening the knowledge about the conflict 
and the development of conflict solving skills, for instance $« I f \ldots I$ would .... developing quick reaction on conflict situation. All participants take part in the training working in a circle: the first person declares a condition: If I am offended in public transport..., the person next to him should finish the sentence. Thus, the following questions are discussed: Whose problem solution was the best? Whose problem was real and true to life?

The aim of the training exercise «Argument against» is to work out discussion skills and give arguments against in small groups where each of the participants should tell the rest about his weak points, those traits of character he or she wants to change. The participants listen carefully and then discuss the above heard giving arguments against. The representatives of micro groups discuss with the rest different arguments against as for overcoming the drawbacks in the behavior of a person taking into consideration the following questions: What can you oppose against the drawbacks? Under what circumstances these weaknesses may turn into strong traits?

«Life incident» training exercise imitates conflict situation in the form of a game where each of the participants tells about the conflict that he witnessed or took part in where the speaker may act as a camera man or script writer etc. The questions for discussion would be as follows: Whose scenario was the best? How can you appreciate this experience of solving conflict situations? Will it be helpful in your future life?

The above mentioned training exercises help to reveal the essence of the notion of conflict, its positive and negative sides. Taking into consideration the permanent presence of conflict in the life of people, our reaction is conditioned by our previous experience and if we think that conflict is a threat, our reaction will be relevant and vice versa. Also our reaction largely depends on how we can solve conflict situation and that is the area of further learning. These exercises were conducted to improve students' background knowledge of conflicts, the social environment that influences them, and techniques for diagnosing certain psychological characteristics of other people.

The concluding part of the training helped to ease the psychological pressure, to relax, receive emotional satisfaction and to summarize the results: Have your expectations come true? What theoretical and practical knowledge did you receive? Training exercise «Conclusions» activates the skills of using obtained information in real life situations, «Applauds» relives psychological pressure etc.
The material clearly demonstrates that training as a form of communication creates a specific social context, and may be considered a symbol of professional growth of future specialists. Students must participate actively in the learning process where training is widely used nowadays helping to form professional skills such as positive interpersonal cooperation, critical thinking, skills of self presentation, self organization and self-control, and the teachers can only facilitate this process on the basis of their own experience and psychological or other peculiarities of the group of students. To achieve these goals teachers-trainers should be aware of the variety of methods of training and understand the effectiveness of each method in a certain group to achieve maximum results $[7$, c. 14].

The last item to consider is the characterization of training technologies used when an ascertaining experiment was conducted, in the process of which, on the basis of certain criteria and their indicators, an analysis of conflictological competence formation stage of future foreign language teachers was carried out; the pedagogical conditions of the studied phenomenon formation were theoretically grounded and the conceptual model of their realization was developed. According to the outline of our experimental work the following trainings have been used: «How do we estimate ourselves?», «How do we estimate others», «Your attitude to the conflict», «Effective conflict solving strategies in educational environment «, «Modern strategies of solving pedagogical conflicts». The respondents studied in higher education establishments, namely: Volodymyr Vynnychenko Central Ukrainian State Pedagogical University, Hryhorii Skovoroda University in Pereiaslav.

Conclusions and prospects for further researches of direction. It is a matter of theoretical as well as practical interest to find out to what extent and in what ways training technologies manifest themselves in formation of conflictological competence of future foreign language teachers. It was clarified that future teachers should be greatly interested in creating positive, peacekeeping and tolerant atmosphere in educational process because today knowledge of the linguistic structure of a language is only one of the requirements of a good language teacher. He should be a symbol of culture and of personal identity with many parts to play: friend, manager, monitor, counselor, facilitator of learning, reliable informant on the language, social worker, model for the students etc. At the contemporary stage of the development of the 
system of education in Ukraine, constant changes of educational priorities, diversity of information conflicts in educational sphere are inevitable, thus high level of conflictological competence will help future teachers to work out their own strategy of overcoming pedagogical conflicts, that is why training technologies are in the focus of attention of many researches today as a very interesting and promising field of investigation.

\section{СПИСОК ДЖЕРЕЛ}

- Бавина П. А. Тренинговые технологии в формировании коммуникативной компетентности будущих менеджеров: автореф. дис. ... канд. пед. наук: 13.00.02. СанктПетербург, 2006. 26 с.

- Бакли Р., Кэйпл Д. Теория и практика тренинга. СПб.: Питер, 2002. 352 с.

- Бондарєва Л. І. Навчальний тренінг як засіб професійної підготовки майбутніх менеджерів організацій в економічних університетах: автореф. дис. на здобуття наук. ступеня канд. пед. наук: спец. 13.00.04 / «Теорія і методика професійної освіти». Київ, 2006. 23 с.

- Вачков И. В. Основы технологии группового тренинга. Психотехники: учеб. пособ. Москва, 1999. 237 с.

- Керик О. Використання тренінгових технологій у професійній підготовці фахівців соціальної сфери. Молодь і ринок. 2015. №2 (121). C. $136-140$.

- Маркова А. К. Профессиональный тренинг, профессиональное самосохранение. Москва: Наука, 1996. 309 с.

- Методичні рекомендації для тренерів щодо розроблення та проведення тренінгів / Автор. кол.: Т. Фулей (керівник робочої групи), Н. Буруковська, Т. Будниченко, Г. Савченко. Київ, «Освіта суддів - для економічного розвитку». $2016.90 \mathrm{c.}$

- Мілютіна К. Л. Теорія та практика психологічного тренінгу: навч. посіб. Київ: МАУП, 2004. 192 с.Шоробура І., Ткаченко Ю. Тренінгові технології у закладах вищої освіти. Молодь і ринок. 2019. №2 (169). С. 6-12.

- Сучасні технології освіти дорослих: посіб. / авт. кол.: Л. Б. Лук'янова, О.В.Аніщенко, Л. С. Сігаєва, С. В. Зінченко, О. В. Баніт, Н. І. Дорошенко. Кіровоград : Імекс-ЛТД, 2013. $182 \mathrm{c}$.

- Федоренко Н. І. Інтерактивне навчання у вищій освіті: ефективне використання тренінгових технологій. Актуальні проблеми соціології, психології, педагогіки. 2015. №1 (26). C. $155-160$.

\section{REFERENCES}

1. Bavyna, P. A. (2006). Trenynhovble tekhnolohyy $v$ formyrovanyy kommunykatyvnoi kompetentnosty budushchykh menedzherov. [Training technologies in formation of communicative competence of future managers]. SanktPeterburh.

2. Bakly, R., Kэipl, D. (2002) .Teoryia y praktyka trenynha. [Theory and practice of training]. Pyter .

3. Bondarieva, L. I. (2006). Navchalnyi treninh yak zasib profesiinoi pidhotovky maibutnikh menedzheriv orhanizatsii $v$ ekonomichnykh universytetakh. [Educational training as means of professional preparation of future managers in Economic Universities]. Kyiv.

4. Vachkov, Y. V. (1999). Osnovbl tekhnolohyy hruppovoho trenynha. [The basic technologies of group training]. Moscow.

5. Keryk, O. (2015). Vykorystannia treninhovykh tekhnolohii $u$ profesiinii pidhotovtsi fakhivtsiv sotsialnoi sfery. [The usage of training technologies in professional preparation of social sphere specialists].

6. Markova, A. K. (1996). Professyonalnbii trenynh, professyonalnoe samosokhranenye. [Professional training, professional self-preservation]. Moscow.

7. Metodychni rekomendatsii dlia treneriv shchodo rozroblennia ta provedennia treninhiv. (2016). [Guidelines for trainers as for working out and conducting trainings]. Kiiv.

8. Miliutina, K. L. (2004). Teoriia ta praktyka psykholohichnoho treninhu: navch. posib. [Theory and practice of psychological training: ed.manual ]. Kiiv.

9. Suchasni tekhnolohii osvity doroslykh. [Contemporary technologies of adult education]. Kirovohrad.

10. Fedorenko, N.I. (2015). Interaktyvne navchannia $u$ vyshchii osviti: efektyvne vykorystannia treninhovykh tekhnolohii. [Interactive learning in high school: effective usage of training technologies].

\section{ВІДОМОСТІ ПРО АВТОРА}

ПОЛІщУК Ганна Віталіївна - кандидат філологічних наук, доцент кафедри англійської мови та методики іiі викладання Центральноукраїнського державного педагогічного університету імені Володимира Винниченка.

Наукові інтереси: теорія і методика вищої освіти, конфліктологія,

\section{INFORMATION ABOUT THE AUTHOR}

POLISHCHUK GannaVitalievna - Ph.D in Philology, Assistant Professor of the Chair of the English Language and its Teaching Methods, Volodimir Vinnichenko Central Ukrainian State Pedagogical University.

Circle of scientific interests: theory and methods of high education, conflict studies.

Стаття надійшла до редакиії 01.11.2020 p. 